\title{
Enhancing Student's Understanding in Feasible Study Subject by Using Blended Learning Methods (Mind Mapping, Project Based Learning and Coursera)
}

\author{
Winny Alna Marlina ${ }^{1, *}$ Devi Yulia Rahmi ${ }^{2}$ Rizki Antoni ${ }^{3}$
}

\author{
1, 2, Department of Management, Andalas University, Padang, Indonesia \\ ${ }^{3}$ State Universit of Medan, Medan, Indonesia \\ ${ }^{*}$ Corresponding author. Email: winnyalnamarlina@eb.unand.ac.id
}

\begin{abstract}
Business Feasibility Study is a mandatory subject that students learn in Management Department to determine a business feasibility. Teaching method in Business Feasibility Study use Student Centred Learning. The result of this method shows that students grades are below average. The aim of this research is to determine the possible increase in student understanding in Business Feasibility Study Subjects using Mind Mapping, Project Based Learning and Coursera Methods at the In the Management Department of the Economics Faculty of Andalas University. The research method is quantitative. Survey methods were used for data collection. The research used a sample of 88 students. In this study, the data were analysed and processed using the Software Statistics Program for Social Science with the Multiple Linear Regression analysis method. Data collection techniques in this research were done using questionnaires. The results of the study provide four empirical evidences related to the increase of students understanding in business feasibility studies using mind mapping, project based learning methods and coursera.
\end{abstract}

Keywords: Blended Learning Methods, Teaching Methods, Mind Mapping

\section{INTRODUCTION}

[1] "Business Feasibility Study is a subject that evaluate the feasibility of a business by considering market and marketing aspects, legal aspects, technical and technological aspects, environmental aspects, management and organizational aspects and financial aspects. The purpose of the Business Feasibility Study subject, is to encourage students are required to find creative and innovative business ideas and to examine them in reports to determine whether the business is feasible or not" (Kasmir and Jakfar, 2003).

"By following the Business Feasibility Study subject students are trained to bring up business ideas to improve student's communication skills, analysis and teamwork. After attending a business feasibility study course, students are able to design an organizational structure that matches the type of business created and carry out management functions (planning, organizing, staffing, directing and controlling and evaluating).

[2] By studying production systems, students apply logical, critical, systematic, and innovative thinking in the context of developing or implementing science and technology in accordance with their area of expertise and managing learning independently and making appropriate decisions in the context of problem solving in their area of expertise" (Marlina, 2019).

Around 123 students from 2018 to 2019 followed the Business Feasibility Study course. There were 85 female students and 37 male students. The percentage of students taking part in the Business Feasibility Study Course can be seen in Figure 1. 


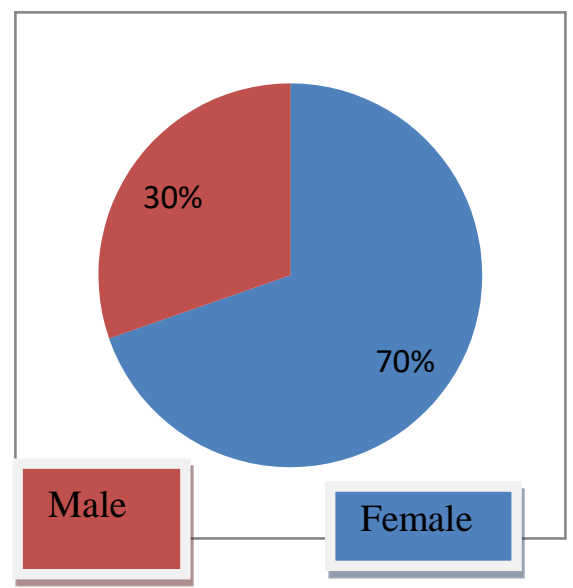

Figure 1. The percentage of students taking the Business Feasibility Study subject

After applying Student Central Learning, the distribution of student scores are varied. Total A scores amounted to 11 people out of 123 students and D scores totalled 25 students, so the percentage of students getting grades from $\mathrm{A}$ to $\mathrm{B}$ was $35 \%$. For the distribution grades of Business Feasibility Study subject in Figure 2.

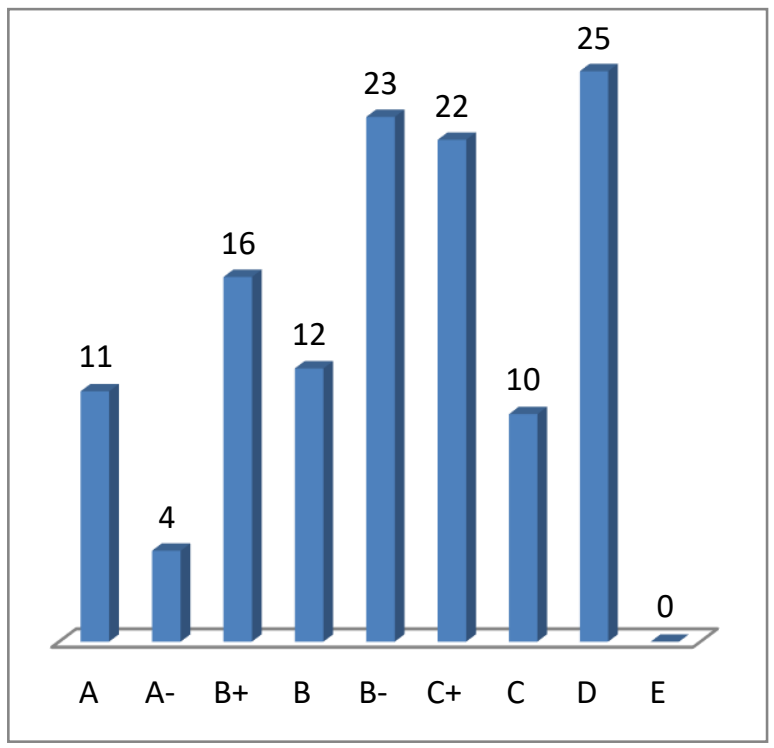

Figure 2. The distribution grades of students

From figure 2 shows that 25 students got D grades, 10 students got $\mathrm{C}$ grades, 22 students got $\mathrm{C}+$ grades, 23 students got B- grades in the Business Feasibility Study subject.

The Pareto chart to figure out the student problem are shown in Figure 3

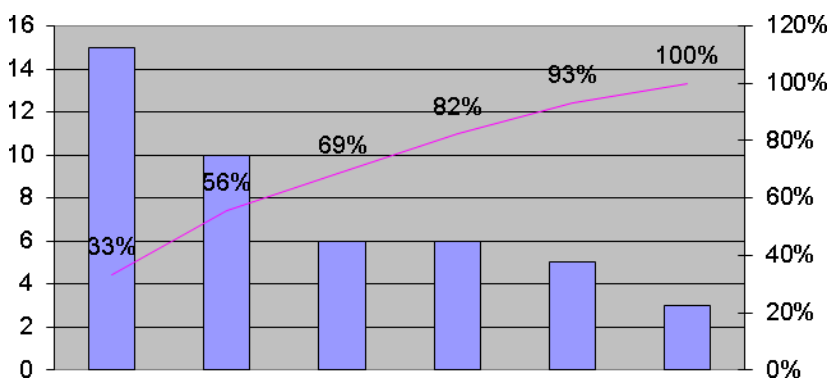

Figure 3. Pareto of problems students in Business Feasibility Study Subject

Pareto chart shows that the problem of students in Business Feasibility Study Subject is $33 \%$ does not understand of this subject, that is why a learning method should change so that Business Feasibility Study subject are easily understood by students, and learning outcomes can be achieved.

The aims of this study is to determine the possible increase in students understanding in Business Feasibility Study Subjects using Mind Mapping and Project Based Learning methods and Coursera in the Management Department of the Economics Faculty of Andalas University, Campus II Payakumbuh. The research design can be seen in Table 1.

Table 1. The research design used

\begin{tabular}{c|l|l}
\hline No & Old Method & New Method \\
\hline 1. & Brainstrorming & Mindmapping \\
\hline 2. & Self-Directed Learning & Coursera \\
\hline 3. & Discovery Learning & $\begin{array}{c}\text { Project Based } \\
\text { Learning }\end{array}$ \\
\hline 4. & Small Group Discussion & Panel Discussion \\
\hline
\end{tabular}

\section{RESEARCH METHODS}

[3] The research method used in research is quantitative. Quantitative method uses data in the form of numbers collected through structured questions (Sekaran, 2017). Research Objectives to determine the increase in student understanding in Business Feasibility Study course using Mind Mapping, Project Based Learning and Coursera. 
Table 2 Research Design

\begin{tabular}{l|l}
\hline $\begin{array}{l}\text { The type of } \\
\text { research }\end{array}$ & Explanatory Research \\
\hline Research Methods & $\begin{array}{c}\text { Survey Explanatory } \\
\text { Kuantitatif }\end{array}$ \\
\hline Time Horizon & $\begin{array}{c}\text { One shot Study (Cross- } \\
\text { Sectional 2020) }\end{array}$ \\
\hline Analysis Unit & $\begin{array}{l}\text { Student who took the } \\
\text { Business Feasibility Study } \\
\text { Course at the Faculty of } \\
\text { Economics, Department of } \\
\text { Management, Andalas } \\
\text { University, Campus II } \\
\text { Payakumbuh }\end{array}$ \\
\hline
\end{tabular}

In this study, the data were analysed and processed using the Software Statistics Program for Social Science (IBM SPPS) version 20 with the method of Multiple Linear Regression analysis.

Data collection techniques in this research were done using questionnaires. According to Sekaran (2017) the questionnaire is a list of written questions where respondents will look for answers that they think are appropriate to their circumstances, usually among clearly defined alternatives.

According to Sekaran (2017) the population refers to the whole group of people, events, or interesting things that investigators want to investigate. The population in this study were 114 students who took the Business Feasibility Study Course at the Faculty of Economics, in Andalas University, Campus II Payakumbuh

According to Sekaran (2017) the sample is a subset or subgroup of a population, the method used in this study is probability sampling. The sample in this research uses the Slovin method.

With the following formula:

$$
\begin{gathered}
\mathbf{n}=\frac{\mathrm{N}}{\mathbf{1 + \mathrm { Ne } ^ { 2 }}} \\
\mathbf{n}=\frac{114}{1+114(0,05)^{2}} \\
\mathbf{n}=\mathbf{8 8}
\end{gathered}
$$

Where:

$\mathrm{n}=$ number of samples

$\mathrm{N}=$ number of pupils (114 students)

$\mathrm{e}=5 \%$ error rate

The number of research samples $=88$ students
Processing consists of:

a. Test the validity with construct validity, where the validity test is done by calculating the correlation coefficient ( $\mathrm{r}$ arithmetic) between the statement items of each variable with $r$ tables. To obtain the value of $r$ arithmetic researchers used a tool in the form of SPSS Software version 20. The value of $r$ arithmetic can be seen from the Pearson Correlation value of each statement item in this study. [4] The validity test criteria according to Suharyadi \& Purwanto (2013) is that if the $r$ count value or Pearson Correlation value is greater than ( $>$ ) $r$ table value then the statement item can be said to be valid. Validity test is done to prove an instrument, technique, or process used really measures the concept in question (Sekaran, 2017).

b. Reliability test with reliability coefficient. According to Sekaran (2017) reliability is carried out to find out whether the answers filled in by respondents on the questionnaire remain consistent if asked repeatedly using a questionnaire that is equal to Cronbach's alpha value> 0.60 , then measuring instrument is considered reliable.

c. The method of multiple linear regression, because this study is to predict the effect of two or more independent variables $(\mathrm{X})$ on one dependent variable (Y). According Suharyadi \& Purwanto (2013) regression analysis is used to build equations that connect the dependent variable (Y) with the independent variable $(\mathrm{X})$ and to calculate the forecast or guess value. [5] According to Santoso (2014) the general form of multiple regression equations, namely:

In this study, the independent variable $(\mathrm{X})$ used is the Learning Method with Mindmapping (X1), the Learning Method with Project Based Learning (X2), the Learning Method with Coursera (X3), while the dependent variable (Y) is Student Understanding of the subject Business Feasibility Study.

The form of the multiple regression equation in this study is as follows:

$$
\mathrm{Y}=\boldsymbol{\alpha}+\boldsymbol{\beta 1 X 1}+\boldsymbol{\beta 2} \mathrm{X2}+\ldots+\boldsymbol{\beta n X n}+\mathrm{e}
$$

Information:

$\mathrm{Y}=$ Student Understanding

$\alpha=$ Constant of the regression equation

$\beta 1=$ Regression coefficient of variable X1,

Learning Method with Mind mapping

$\beta 2=$ Regression coefficient of X2 variable,

Learning Method with Coursera

$\beta 3=$ Regression coefficient of variable X3, 
Learning Method with Coursera

X1 = Method of Learning with Mind mapping

X2 $=$ Method of Learning with Mind mapping

X3 = Learning Method with Coursera

$\mathrm{e}=$ Confounding Variable

d. T test was conducted to determine the effect of individual independent variables on the dependent variable. The hypothesis for the $\mathrm{T}$ test can be formulated as follows:

1. H0: Learning Method with Mindmapping does not increase student understanding in Business Feasibility Study Subjects

H1: Learning Method with Mindmapping improves student understanding on Business Feasibility Study Subjects

2. H0: Learning Method with Project Based Learning does not increase student understanding in Business Feasibility Study Subjects

H1: Learning Method with Project Based Learning increases student understanding in Business Feasibility Study Subjects

3. H0: Learning Method with Project Based Learning does not increase student understanding in Business Feasibility Study Subjects

H1: Learning Method with Project Based Learning increases student understanding in Business Feasibility Study Subjects

e. F test was performed to determine the effect of the independent variable (X) simultaneously on the dependent variable (Y).

f. Adjusted R square (Adjusted R2) is used to measure the ability of the model to explain variations in the dependent variable. If the Adjusted R square value approaches number 1 , it means the relationship between the independent variable and the dependent variable is getting closer. In other words, the independent variable provides almost all the information needed to predict the variation of the dependent variable.

\section{RESULTS AND DISCUSSION}

Questionnaires were distributed directly to respondents within a month, starting from April 26, 2018 to May 26, 2020. The data obtained were used as the main material for data analysis. Survey methods were used for data collection. [6] The survey method was chosen because of its possibility to obtain large volumes of data in a relatively short period of time, as well as with relatively more economical costs (Cooper and Schindler, 2014). Furthermore, researchers distributed questionnaires to respondents who were considered relevant and matched the required criteria for filling out the questionnaire.

Table 3. Results of the Distribution of Research Questionnaire

\begin{tabular}{|c|c|c|}
\hline Information per Individu & Amount & $\begin{array}{l}\text { Percentage } \\
(\%)\end{array}$ \\
\hline Questionnaire & 114 & 100 \\
\hline $\begin{array}{l}\text { The questionnaire } \\
\text { returned }\end{array}$ & 88 & 77,1 \\
\hline $\begin{array}{l}\text { Questionnaires that } \\
\text { cannot be analyzed / } \\
\text { questionnaires } \\
\text { incomplete } \\
\text { questionnaire } \\
\text { numbers less than } \\
\text { half of team members }\end{array}$ & (0) & $(0)$ \\
\hline $\begin{array}{l}\text { Questionnaire that } \\
\text { can be analyzed }\end{array}$ & 88 & 77,1 \\
\hline Total (Response Rate) & 88 & 77,1 \\
\hline
\end{tabular}

Source: Primary data processed (2020)

The unit of analysis used in this study is individuals who take Business Feasibility Studies as a subject. Questionnaires were distributed to 114 respondents. However, from 114 students only 88 students (77.1\%) returned the questionnaire. This number is considered enough, in accordance with the minimum number of samples required in this study.

\subsection{Profile of Respondents}

Characteristics of individual respondents in this study include age (age), last education, cumulative achievement index (GPA), and number of courses taken in the current semester (even 2019/2020). For more details, the percentage breakdown regarding individual respondents' profiles is shown in Table 4.

Table 4. Profile of Respondents

Profile of Respondents Amount Persentase

$(\%)$

(Age) of Respondents

$\begin{array}{lll}20 \text { years old } & 13 & 14,7 \\ 21 \text { years old } & 29 & 32,9 \\ 22 \text { years old } & 38 & 43,1 \\ 23 \text { years old } & 6 & 6,8 \\ 24 \text { years old } & 2 & 2,2\end{array}$




\begin{tabular}{|c|c|c|c|c|c|c|}
\hline \multirow{2}{*}{$\begin{array}{l}\text { Total } \\
\text { Latest Education }\end{array}$} & \multirow[t]{2}{*}{88} & \multirow[t]{2}{*}{100} & \multicolumn{4}{|c|}{ Table 5. Validity Test Results } \\
\hline & & & & & & \\
\hline Senior High School & 88 & 100 & \multicolumn{2}{|c|}{ Variables and Indicators } & \multicolumn{2}{|c|}{ Validity Tes } \\
\hline \multirow{2}{*}{ Total } & \multirow{2}{*}{88} & \multirow{2}{*}{100} & & & R Count & $\mathrm{r}$ table \\
\hline & & & \multirow[t]{5}{*}{ Mindmapping } & Mind1 & 0,837 ** & 0,174 \\
\hline $2,00-2,50$ & 2 & 2,2 & & Mind2 & $0,806^{* *}$ & 0,174 \\
\hline $2,51-3,00$ & 10 & 11,3 & & Mind3 & $0,753 * *$ & 0,174 \\
\hline $3,01-3,50$ & \multirow[t]{2}{*}{67} & 76,1 & & Mind4 & $0,825^{* *}$ & 0,174 \\
\hline $3,51-4,00$ & & 1 & & Mind5 & $0,800 * *$ & 0,174 \\
\hline \multirow{2}{*}{ Total } & \multirow{2}{*}{88} & \multirow{2}{*}{100} & \multirow{5}{*}{$\begin{array}{c}\text { Project } \\
\text { Based Learning }\end{array}$} & PBL1 & $0,847^{* *}$ & 0,174 \\
\hline & & & & PBL2 & $0,848 * *$ & 0,174 \\
\hline 1 subject & 18 & \multirow{2}{*}{20,4} & & PBL3 & $0,726^{* *}$ & 0,174 \\
\hline 2 subject & 13 & & & PBL4 & $0,846^{* *}$ & 0,174 \\
\hline 3 subject & 1 & 14,7 & & PBL5 & $0,828 * *$ & 0,174 \\
\hline 4 subject & 4 & 4,5 & \multirow[t]{2}{*}{ Coursera } & Cour1 & $0,851 * *$ & 0,174 \\
\hline 5 subject & 3 & 3,4 & & Cour2 & $0,922 * *$ & 0,174 \\
\hline 6 subject & 12 & 13,6 & & Cour3 & $0,934 * *$ & 0,174 \\
\hline 7 subject & 30 & 34 & & Cour4 & $0,899 * *$ & 0,174 \\
\hline 8 subject & 7 & 7,9 & & Cour5 & $0,884 * *$ & 0,174 \\
\hline Total & 88 & 100 & Student & Pema1 & $0,638 * *$ & 0,174 \\
\hline Source: Primary d & $(2)$ & & Understanding & Pema2 & $0,732 * *$ & 0,174 \\
\hline Based on age, responde & this & wer & & Pema3 & $0,729 * *$ & 0,174 \\
\hline dominated by young people $\mathrm{w}$ & people & $1 \%$ of & & Pema4 & $0,844 * *$ & 0,174 \\
\hline 22 years of age, $100 \%$ respond & e a hi & oll / & & Pema5 & $0,814 * *$ & 0,174 \\
\hline
\end{tabular}

$76.1 \%$ of the respondents had a GPA of 3.01-3.50.

\subsection{Validity test}

"Research instruments must be tested to determine whether an instrument is valid or not. Testing the validity of research instruments is conducted to assess whether an instrument is able to measure what it wants to measure in a scientific study" (Cooper \& Schindler, 2014).

The validity test that was carried out was the construct validity test which is a way to calculate the correlation coefficient ( $\mathrm{r}$ arithmetic) between the statement items of each variable with $r$ tables.
Note $=* *$ sig level $0.05, \mathrm{~N}=88$

\section{Source: Primary data processed (2020)}

Table 5. show the results of the validity test by comparing $r$ count and $r$ table. The significance level is 0.05 with a sample size of 88 . From Table 5. it appears that all items for each variable are valid.

\subsection{Reliability Test}

[7] "Reliability test is a test to measure whether the research instrument that researchers use has consistency or reliability in measuring the variables or constructs used in this study" (Sugiono, 2013). [7]The research instrument can be said to be reliable if a person's answer to the research instrument continuously has consistency, accuracy, and precision. "Consistency is a key requirement in testing reliability, because it will measure homogeneity between measurement instruments that reflect the construct. Internal 
consistency can be measured using Cronbach's alpha values which assess a positive relationship to the number of items in the scale." (Hair et al., 2014). "The acceptable Cronbach's alpha score is a minimum of 0.6." (Now, 2017).

The overall test results of the measurement instruments used in this study can generally be stated to be reliable, seen from the Cronbach's alpha value $\geq 0.6$.

Table 6 shows the reliability test results of all research instruments in more detail.

Table 6 Cronbach's Alpha Values

\begin{tabular}{lcc}
\hline \multicolumn{1}{c}{ Variable } & $\begin{array}{l}\text { Cronbach's } \\
\text { Alpha }\end{array}$ & Description \\
\hline Mindmapping & 0,906 & Reliabel \\
Project Based Learning & 0,918 & Reliabel \\
Coursera & 0,959 & Reliabel \\
Student Understanding & 0,867 & Reliabel \\
\hline
\end{tabular}

Source: Primary data processed (2020)

\subsection{T Test (Partial)}

T test (partial) was conducted to determine the effect of individual independent variables on the dependent variable. The hypothesis for the $\mathrm{T}$ test can be formulated as follows:

Table 7 Test Results Significance T (Partial)

\begin{tabular}{ccc}
\hline Effect & $\begin{array}{c}\text { Adjusted R } \\
\text { Square }\end{array}$ & $\begin{array}{c}\text { Standardizes } \\
\text { Coefficient }(\beta)\end{array}$ \\
\hline Mind $\rightarrow$ Pema & 0,306 & $0,560^{* *}$ \\
PBL $\rightarrow$ Pema & 0,401 & $0,639^{* *}$ \\
Cour $\rightarrow$ Pema & 0,347 & $0,595^{* *}$ \\
\hline
\end{tabular}

Note: $* *$ indicates significant at the 0.05 level.

\section{Source: Primary data processed $(\mathbf{2 0 2 0})$}

The first hypothesis in this study states that the mind mapping learning method increases student understanding of business feasibility studies. In Table 3.5 Mind $\rightarrow$ Pema shows the results of mind mapping variable regression testing on student understanding in business feasibility study subjects. The results of the regression analysis showed that mind mapping had a positive and significant effect on student understanding $(\beta=0.560 \mathrm{p}<0.05)$. Thus, the influence of mind mapping on student understanding can be said to be positive and significant; therefore the first hypothesis can be considered validated.

The second hypothesis in this study states that the method of learning with project based learning increases student understanding on business feasibility study subjects. In Table 3.5 PBL $\rightarrow$ Pema shows the results of the project based learning variable regression testing on student understanding in business feasibility study subjects. The results of the regression analysis showed that project based learning had a positive and significant effect on student understanding $(\beta=0.639 \mathrm{p}<0.05)$. Thus, the effect of project based learning on student understanding can be said to be positive and significant; therefore, the second hypothesis can be considered validated.

The third hypothesis in this study states that the use of the website "coursera" increases students' understanding of business feasibility study subjects. In Table 3.5 Cour $\rightarrow$ Pema shows the results of coursera variable regression testing on student understanding in business feasibility study subjects. The results of the regression analysis showed that coursera had a positive and significant effect on student understanding $(\beta=$ $0.595 \mathrm{p}<0.05)$. Thus, the influence of coursera on student understanding can be said to be positive and significant; therefore the third hypothesis can be considered validated.

The adjusted R Square value for each mind mapping variable, project based learning, and coursera is 0.306 ; 0.401 ; and 0.347 . This value indicates that each of the mind mapping variables, project based learning, and coursera influences the understanding of students in business feasibility study subjects respectively by $30.6 \% ; 40.1 \%$ and $34.7 \%$

\subsection{Mindmapping Learning Methods Affect Student Understanding in Business Feasibility Study Subjects}

The first hypothesis states that mindmapping learning methods significantly influence student understanding of business feasibility studies. The regression equation (see Table 3.5) shows that this hypothesis is supported.

In mindmapping learning methods conducted by students is by describing business ideas in the notes forming patterns of ideas related to topics in the middle and subtopics become branches. Furthermore, students show the results of business ideas in mindmapping in the classroom. Meanwhile, the lecturer acts as a facilitator. These findings reinforce that students like when facilitated by mindmapping learning methods by lecturers. The learning process by using mindmapping is also very easy to learn so that students can independently understand the subject. And by using mindmapping learning methods make students able to act actively in the classroom. 


\subsection{Project Based Learning Methods Affect} Student Understanding in Business Feasibility Study Subjects

The second hypothesis states that the project based learning method has a significant effect on students' understanding of business feasibility studies. The regression equation (see Table 3.5) shows that this hypothesis is supported. In the method of learning project based learning by students is to do assignments (in the form of projects) that have been systematically designed. Furthermore, students show their performance and take responsibility for their work in the forum. Meanwhile the lecturer is in charge of formulating and conducting the guidance and assessment process. The lecturer also designs a systematic assignment (project) so that students learn knowledge and skills through a structured search process. These findings reinforce that students like when facilitated by the method of learning project based learning by lecturers. The learning process by using project based learning is also very easy to learn so that students can independently understand the subject. And by using the project based learning method of learning makes students able to act actively in the classroom.

\subsection{Coursera Learning Method Affects Student Understanding in Business Feasibility Study Subjects}

The third hypothesis states that the coursera learning method significantly influences students' understanding of business feasibility studies. The regression equation (see Table 3.5) shows that this hypothesis is supported.

In the coursera learning method conducted by students is to watch learning videos related to Business Feasibility Studies. Then students make a review of what has been learned by following coursera and answering exercises in coursera. Lecturers in this case examine the results of learning obtained online from coursera and provide feedback to students. These findings reinforce that students like when facilitated by coursera learning methods by lecturers. The learning process using coursera is very easy to learn so that students can understand independently of the course. And by using the coursera learning method, students can act actively in the classroom.

\subsection{Mindmapping Learning Methods, Project Based Learning, and Coursera Influence Student Understanding in Business Feasibility Study Subjects}

The fourth hypothesis states that mindmapping, project based learning, and coursera learning methods together have a significant effect on students' understanding of business feasibility courses. The regression equation (see Table 3.6) shows that this hypothesis is supported. These findings reinforce that students choose mindmapping learning methods, project based learning, and coursera. Students better understand business feasibility study subjects when delivered with mindmapping methods, project based learning, and coursersa

\section{CONCLUSION}

In general, this research is an explanatory research, which aims to find out the increase in students' understanding in business feasibility studies using mind mapping, project based learning and coursera methods. The unit of analysis of this research is students who take Business Feasibility Study Courses at the Faculty of Economics, Department of Management, Andalas University, Campus II Payakumbuh. The object of this study consisted of 88 respondents.

The results of the study provide four empirical evidence related to increasing student understanding in business feasibility studies using mindmapping, project based learning and coursera methods. The first empirical finding states that mindmapping learning methods increase student understanding in business feasibility study subjects. The second empirical finding concludes that the method of learning with project based learning increases students' understanding of business feasibility studies. The third empirical finding states that learning methods with project based learning increase student understanding in business feasibility study subjects. And the fourth empirical finding states that learning methods with mindmapping, project based learning and coursera improve student understanding in business feasibility studies.

The first hypothesis in this study states that the mind mapping learning method increases student understanding of business feasibility studies. In Table 3.5 Mind $\rightarrow$ Pema shows the results of mind mapping variable regression testing on student understanding in business feasibility study subjects. The results of the regression analysis showed that mind mapping had a positive and significant effect on student understanding $(\beta=0.560 \mathrm{p}<0.05)$. Thus, the influence of mind mapping on student understanding can be said to be positive and significant; therefore, the first hypothesis can be considered validated.

The second hypothesis in this study states that the method of learning with project based learning increases student understanding on business feasibility study subjects. In Table 3.5 PBL $\rightarrow$ Pema shows the results of the project based learning variable regression testing on student understanding in business feasibility study subjects. The results of the regression analysis showed that project based learning had a positive and significant effect on student understanding $(\beta=0.639 \mathrm{p}<0.05)$. Thus, the effect of project based learning on student understanding can be said to be positive and significant; therefore, the second hypothesis can be considered validated. 
The third hypothesis in this study states that the use of the website "coursera" increases students' understanding of business feasibility study subjects. In Table 3.5 Cour $\rightarrow$ Pema shows the results of coursera variable regression testing on student understanding in business feasibility study subjects. The results of the regression analysis showed that coursera had a positive and significant effect on student understanding $(\beta=$ $0.595 \mathrm{p}<0.05)$. Thus, the influence of coursera on student understanding can be said to be positive and significant; therefore, the third hypothesis can be considered validated.

The adjusted R Square value for each mind mapping variable, project based learning, and coursera is 0.306 ; 0.401 ; and 0.347 . This value indicates that each of the mind mapping variables, project based learning, and coursera influences the understanding of students in business feasibility study subjects respectively by $30.6 \% ; 40.1 \%$ and $34.7 \%$.

\section{ACKNOWLEDGMENT}

This work was supported by LP3M Andalas University. Thank you for students who participated for survey.

\section{REFERENCES}

[1] Kasmir and Jakfar. (2003). Studi Kelayakan Bisnis. Perdana Media Group. Bogor.Cooper, Donald R., dan Pamela S. Schindler. 2014. Business Research Methods. Twelfth Ed. Florida: McGraw Hill.

[2] Marlina, Winny. (2019). Penggunaan Kahoot Sebagai Media Belajar Berbasis Web Untuk Mahasiswa Management Campus 2 Unand Payakumbuh. Universitas Andalas. Padang: LP3M

[3] Hair, Joseph F., William C. Black, Barry J. Babin, dan Rolph E. Anderson. 2014. Multivariate Data Analysis. Seventh Ed. Vectors: Prentice Hall.

[4] Sekaran, U. (2017). "Research Methods for Business (Metodologi Penelitian untuk Bisnis)" (6th Ed.). Salemba Empat.

[5]. Suharyadi., \& Purwanto S. H. (2013). Statistika untuk Ekonomi dan Keuangan Modern. Jakarta: Salemba Empat.

[6] Cooper, Donald R., dan Pamela S. Schindler. 2014. Business Research Methods. Twelfth Ed. Florida: McGraw Hill.

[7] Sugiyono, Uma. (2013). Metode Penelitian Bisnis. Bandung: Alfabeta
[8] Hair, Joseph F., William C. Black, Barry J. Babin, dan Rolph E. Anderson. 2014. Multivariate Data Analysis. Seventh Ed. Vectors: Prentice Hall

[9] Oweis Thelal Iqab. (2018). Effects of Using a Blended Learning Method on Students' Achievement and Motivation to Learn English in Jordan: A Pilot Case Study. Education Research International, Volume 2018, Article ID 7425924, 7 pages https://doi.org/10.1155/2018/7425924

[10] Tawil, Hanan. (2018). The Blended Learning Approach and Its Application in Language Teaching. International Journal of Language and Linguistics.Vol. 5, No. 4, December 2018.

[11] Universitas Hasanuddin. (2017). Silabus Studi Kelayakan Bisnis. Hal 1-

[12] Dinning et all. (2015). Can A Blended Learning Approach Enhance Students' Transition Into Higher Education? A Study To Explore Perceptions, Engagement And Progression. International Journal of Advancement in Education and Social Science, Vol.3, No.2 